\title{
Accounting
}

\section{Reasons behind accounting information tools adopted by Portuguese third sector organizations}

\author{
Eurico Basto $^{a}$, Amélia Ferreira da Silva ${ }^{b^{*}}$ and Anabela Silva
}

${ }^{a}$ Porto Accounting and Business School, Porto Polytechnic, Portugal

${ }^{b}$ CEOS.PP - Centre for Organizational and Social Studies; Porto Polytechnic, Portugal

${ }^{c}$ University of Minho, Portuga

\begin{tabular}{|c|c|}
\hline CHRON I CLE & A B S T RACT \\
\hline $\begin{array}{l}\text { Article history: } \\
\text { Received November } 292019 \\
\text { Received in revised format } \\
\text { December } 262019 \\
\text { Accepted January } 262020 \\
\text { Available online } \\
\text { January } 262020 \\
\text { Keywords: } \\
\text { Third Sector } \\
\text { Accounting Tools }\end{array}$ & $\begin{array}{l}\text { This paper attempts to identify the reasons behind the adoption of the accounting information tools } \\
\text { which has been implemented in Portuguese third sector organizations. The research was designed to } \\
\text { face new institutional theory with rational choice theory. Data was collected from third sector } \\
\text { organizations operating in Portugal. The questionnaire applied was based on earlier literature. Results } \\
\text { support the theoretical perspective of institutionalism. Indeed, third sector organizations operating in } \\
\text { Portugal use essentially traditional accounting tools like financial accounting statements, cost } \\
\text { accounting and budgeting, and there are clear evidences of coercive isomorphic behaviours. Future } \\
\text { research should consider a qualitative approach to deeply understand how and why these organizations } \\
\text { use accounting tools. }\end{array}$ \\
\hline
\end{tabular}

\section{Introduction}

The term "social economy" has been used by European Union since 1989. The discussion about the similarity or the differences between concepts like social economy, third sector and non-profit sector, is still opened in the international debate (Westlund, 2003), with some scholars arguing that "the third sector is by nature unsuited to singular definitions" (Corry, 2010: 11) and others sustaining that "using a term as 'non-profit sector' as equivalent to third sector is clearly misleading" (Evers, and Laville, 2004: p. 13). But, despite the need for better conceptualization of these terms (Henriksen et al., 2012; Salamon \& Sokolowski, 2016), it is well recognized that organizations operating in the third sector face very particular challenges (Lindsay et al., 2014). The specificity of their missions, the social needs they respond to, and the financial constraints they cope with, together, these circumstances make third sector organizations an interesting subject for research (Anheier \& Seibel, 2013). Moreover, "the third sector is expanding and becoming a growing provider of public, social, and health services in many high-income countries" (Bach-Mortensen et al., 2018: 2), keeping alive the debate about its impacts on employment (Westlund, 2003), innovation (Potts $\&$ Hartley, 2015) and economic development (Nega \& Schneider, 2014). The current tendency is for third sector became social business. According to ILO (2011), social business, or social enterprise, is an emerging concept worldwide, and it can be defined as an organization that is run like a business but exists for a social purpose. The social business approach co-exist with traditional non-profit organization that run in 'social economy'. However, social business (or social enterprises) are changing the way we see the economic world. The purpose of organizations to interfere in public causes - elderly support, child and young education,

* Corresponding author.

E-mail address: $\underline{\text { acfs@iscap.ipp.pt (A. Ferreira da Silva) }}$ 
health care, immigrants integration, gender equality, future work and employment, digital inclusion, sustainable development and several others - while being a services and commercial provider is something new in contemporary economics and finance. It opens up 'social economy' to a wider diversity of financial mechanisms.

This process of running non-profit organizations like business, comprising multiple features of the market/hierarchy/network or state/business/community triptychs, are identified by Skelcher and Smith (2015: 434) as a process of organizational hybridity that happened when entities "face a plurality of normative frames" and "contradictions between institutional logics". Just like New Public Management did in public management field, it opens up a promising research agenda on a topic of considerable academic and practical significance. We aim to contribute to this debate by adding some light about the role of accounting tools in current environment of social economy organizations. Even though there is a general perception that Portuguese social economy organizations have structured their accounting information systems in a very elementary way, as far as the authors are aware, no systematic study exists to support this perception. Several theories attempt to explain managers' motivations behind the decision about the adoption of accounting and management tools (Ax \& Greve, 2017). The institutional approach is particularly relevant to the analysis of organizational behaviour and its dynamic. This theoretical perspective makes it possible to understand why organizations are so heterogeneous, on one hand, and why they are so similar, on the other hand. New institutionalism emphasizes the influence of external factors on organizational behaviour arguing that, to receive support and legitimacy, organizations must conform to the dominant rules and requirements of their institutional environment (Meyer \& Scott, 1983). Thereby, organizations within the same environment tend to be isomorphic. This approach focuses on the takenfor-granted nature of organizational forms and practices (DiMaggio, 1988). From this standpoint, accounting tools are adopted to comply with institutional reasons that may be inconsistent with rational economic reasons, such as cost-minimising goals (Moll et al., 2006; Bhimani et al., 2016). An alternative view (rationalism) assumes that rational managers are unlikely to adopt or use accounting tools that do not help them in enhancing performance or do not prove to be useful for decision making or management control (Brierley, 2013).

The purpose of this study is twofold: on one hand, we aim to identify the architectures of accounting information systems implemented in social economy organizations; on the other hand, we intend to go further by understanding the reasons why they were implemented. Therefore, we are confronted with two conflicting theories - institutional theory versus rational choice. The paper is structured as follows. The next section presents the main ideas and arguments of institutional theory and its contrast with rational choice theory. This is followed by the methodology section, with a brief analysis of the Portuguese third sector and its historical origins and a description about how the questionnaire was constructed and applied. The fourth section presents the empirical findings, followed by the discussion of results. Finally, the main conclusions and contribution of the paper are presented, together with the recognition of research limitations and future research opportunities.

\section{Theoretical framework}

Economic, financial and business research was, for a long period, dictated by the positivism approach (Bryman \& Bell, 2015). This epistemological approach has shaped the research agenda and the theoretical place in the field of organizations (Swanson, 2005). Until the 1970s, accounting research was guided by the aim of developing great models to support decision-making and dominated by quantitative methodologies (Bromwich \& Scapens, 2016; Major, 2017). These studies had the underlying idea that (1) decision-makers are rational and use accounting information optimally, looking for goals such as profit maximization or shareholders' wealth, and (2) there are no other goals and/or conflict situations (Major, 2017). Under this approach, reality is external, singular and objective, researchers are neutral, and "accounting hypotheses can be statistically tested to produce generalizable findings" (Bisman, 2010: 6). More recently, mainly since later in the 1980s, accounting researchers became increasingly interested in studying accounting in the context within which it operates (Messner, 2016; Walker, 2016). Thus, the interpretative paradigm and qualitative methodologies, especially case study research, gained new support in the accounting research agenda (Vaivio, 2008; Parker, 2012; Bromwich \& Scapens, 2016). This represented an epistemological stance guided by the basic assumptions that social practices, including management accounting, are socially constructed phenomena and social actors can change the social rules and practices that guide their behaviour (Rossetto \& Rossetto, 2005; Bromwich \& Scapens, 2016; Hopper \& Bui, 2016; Buscoande Quattrone, 2018). This is a sociological approach which explains that organizations adopt certain practices as a form of legitimation and not primarily for economic reasons (Oyadomari et al., 2008) since decisionmaking does not deal only with rationally and neutral information, rather, the decision-making process in organizations involves factors such as emotions, politics, culture, epistemological limitations, or prejudices (Quattrone, 2016, Saukkonen et al., 2017). Meyer and Rowan (1977) described the institutions as myths, characterized by the values that are accepted as legitimate and as such, over time became institutionalized as the proper way of doing things. In this sense, the demand for legitimacy by the organizations pressure them to adopt positions, policies, programs and ways that are understood as proper, rational and correct and as such, incorporate myths. Under this New Institutional Sociology (NIS), accounting can be studied as an institution within the organization, i.e., a set of routines consisting of habits that make sense to a certain group of people. Theorists of this thinking line began to give more importance to the social, cultural and environmental aspects in which accounting run (Brignall \& Modell, 
2000; Gomes, 2007; ter Bogt \& Scapens, 2018; Piacentini, 2018) and interpret institutional logic as "socially constructed, historical patterns of cultural symbols and material practices, including assumptions, values and beliefs, by which individuals and organizations provide meaning to their daily activity, organize time and space, and reproduce their lives and experiences" (Thornton et al. 2012: 2). DiMaggio and Powell (1983) studied the homogeneity of organizations and the processes by which organizations became isomorphic: coercive, mimetic and normative. Isomorphism is a "constraining process that forces one unit in a population to resemble other units that face the same set of environmental conditions" (DiMaggio and Powell, 1983: p. 149). Early NIS theorists sought to explain how different organisations, in many aspects, conformed to similar standards of behaviour and how they employed similar structures. Moreover, they sought to explain the stability in these standards of behaviour and organisational structures. Based on the seminal work of Abrahamson (1991), Malmi (1999) tried to explain why innovations in management accounting are spread by organizations and how this phenomenon occurs. The theoretical model drawn by Abrahamson (1991) uses four perspectives to explain the diffusion or rejection of technologies in accounting. The four perspectives are described below and are delimited by two dimensions - outside influence and imitation focus.

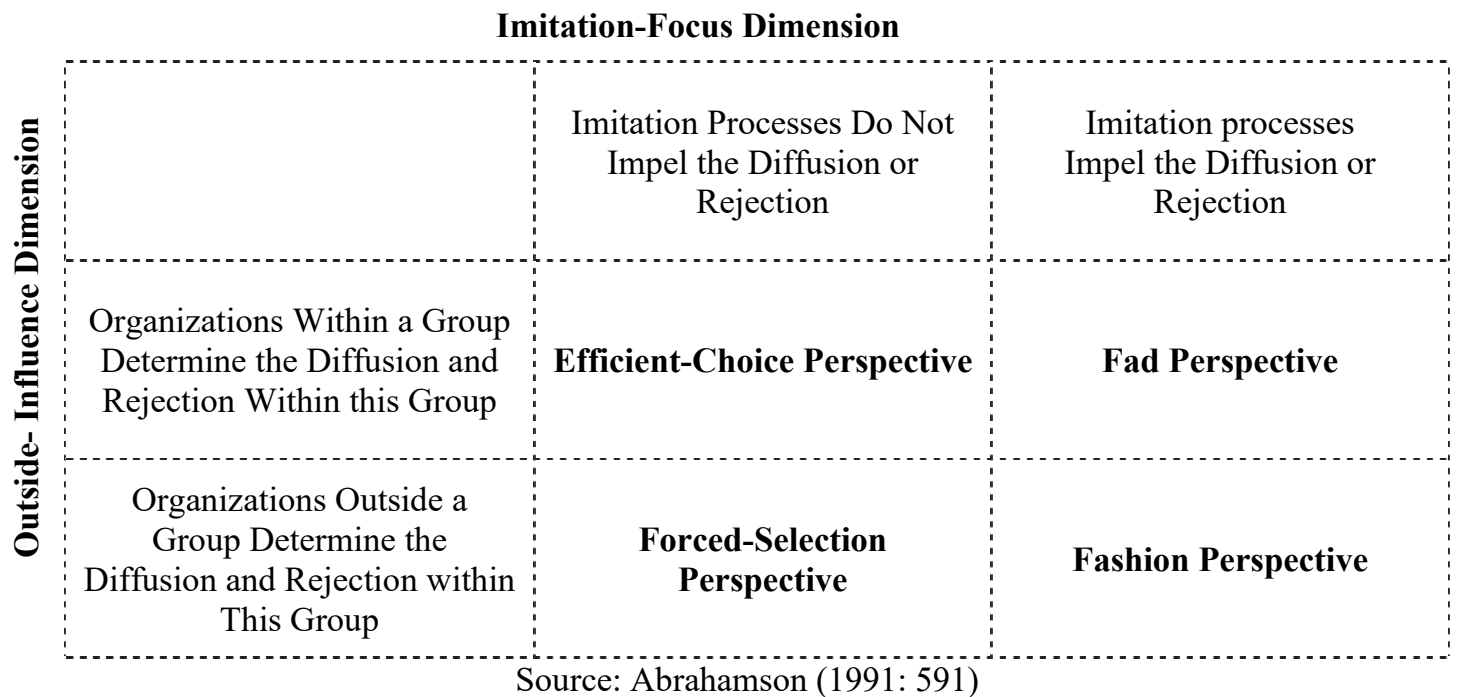

Fig. 1. Explanation of diffusion and rejection of administrative innovations

According to Fig. 1, adoption or rejection of an administrative innovation is framed within four quadrants: Efficient-choice; Forced-selection; Fad, and Fashion. The efficient-choice quadrant is based on two assumptions: (1) organizations can freely and independently choose to adopt an administrative technology and (2) organizations are relatively secure about their goals and about the impact of technology under evaluation in attaining those goals. In other words, individuals are rational decisionmakers, and constantly compare alternatives looking for optimal decisions based on cost-benefit calculations. In contrast to efficient choice, the three other quadrants -Forced-selection; Fad, and Fashion - are based on the assumptions that: (1) organizations will seek external legitimacy; (2) legitimacy is gained by adapting their internal characteristics to conform to expectations of the key stakeholders in their environment. In this sense, Abrahamson's model offers an important tool for a better understanding of the role accounting plays in its day-to-day management activities of third sector organizations in Portugal. This model proposes a direct confrontation of both theoretical perspectives, rational-choice versus institutional theory, but simultaneously dealing with real life ambiguity. There also are gradations between rational and intuitional reasons behind decisions within organizations. Rationality can coexist with no rational behaviours, and so, the question is which one prevails? Abrahamson's model helps us find the answer. The model assumes that processes that prompt the adoption of efficient innovations may coexist with processes that prompt the adoption of inefficient ones. Additionally, it recognizes that this variation depends on the organizational environment (Table 2).

Since third sector organizations are highly dependent on voluntary and public financial contributions, their sustainability is deeply dependent on their reputational capital (Suh \& Amine, 2007). In this case, social legitimization is gained mainly through maximization of social benefits and reproduction of collective values, and thus the ability to be accountable to stakeholders is crucial (Coluccia et al., 2017; Hug \& Jäger, 2014). 


\section{Table 2}

Abrahamson's Model and the Isomorphic Behaviour

\begin{tabular}{|c|c|}
\hline Abrahamson's Model & Isomorphic Behaviour \\
\hline $\begin{array}{l}\text { The forced-selection perspective allows authority to dictate that } \\
\text { administrative innovations are adopted. } \\
\text { This form of power is attributed to the State and the companies that control } \\
\text { other companies, their dependents. This reason for adopting a certain tool is } \\
\text { not considered a valid justification since it does not give any alternative } \\
\text { option. }\end{array}$ & $\begin{array}{l}\text { The coercive isomorphism - regulative pillar (Scott, 2001) - derives from } \\
\text { political influence and legitimacy problems and is the result of formal and } \\
\text { informal pressures exerted by authority or coercive power. }\end{array}$ \\
\hline $\begin{array}{l}\text { Finally, the fad perspective is different from the fashion view, because in } \\
\text { this case of imitating other organization, it is not the models that are trendy } \\
\text { but the other organizations. Organizations tend to imitate other organizations } \\
\text { for legitimacy (DiMaggio and Powell, 1983; Meyer and Rowan, 1977) and / } \\
\text { or to prevent competitors gain competitive advantage (Malmi, 1999). }\end{array}$ & $\begin{array}{l}\text { Mimetic Isomorphism - cogni } \\
\text { imitating the decisions of oth } \\
\text { environment. Organizations se } \\
\text { organizations in various aspects, } \\
\text { seek to achieve and how they w }\end{array}$ \\
\hline $\begin{array}{l}\text { The fashion perspective assumes that, in uncertain circumstances, } \\
\text { organizations tend to imitate the administrative models promoted by } \\
\text { organizations outside of their group, such as consultancy firms whose } \\
\text { mission is the creation or dissemination of these models, nicknamed the } \\
\text { "fashion-setting organizations." The tools promoted in this way may or may } \\
\text { not be efficient. }\end{array}$ & $\begin{array}{l}\text { Normative isomorphism - normative pillar (Scott, 2001) - stemmed from } \\
\text { the professionalization process, and recognized the important role that the } \\
\text { professions (legitimacy of formal education) have in spreading practices and } \\
\text { guidelines to be followed by similar organizations. Professionalization } \\
\text { institutes a set of rules, working methods and procedures specific to a } \\
\text { particular occupation or activity in order to establish a cognitive and } \\
\text { legitimate basis for professional autonomy. }\end{array}$ \\
\hline
\end{tabular}

Source: Own Elaboration

Jäger (2014) distinguished six approaches of non-profit accountability, as summarized in Table 2 as follows,

Table 2

Approaches of non-profit accountability

\begin{tabular}{|c|c|c|c|}
\hline $\begin{array}{c}\text { Strategy } \\
\text { approach }\end{array}$ & $\begin{array}{c}\text { Core } \\
\text { concept }\end{array}$ & To whom is nonprofit accountable? & How does it achieve accountability? \\
\hline $\begin{array}{l}\text { Normative } \\
\text { approach }\end{array}$ & Normative/ ethical & Society & $\begin{array}{l}\text { Moral obligation to provide justifications for the way the } \\
\text { nonprofit aims at achieving its mission. }\end{array}$ \\
\hline $\begin{array}{l}\text { Relational } \\
\text { approach }\end{array}$ & $\begin{array}{l}\text { Embeddedness } \\
\text { stakeholder }\end{array}$ & $\begin{array}{l}\text { Relationships among organizational actors } \\
\text { embedded in a social and institutional } \\
\text { environment } \\
\text { Particular sets of stakeholders }\end{array}$ & $\begin{array}{l}\text { Negotiate criteria measures and interpretation of success } \\
\text { Legitimacy is socially constructed }\end{array}$ \\
\hline $\begin{array}{l}\text { Stakeholder } \\
\text { approach }\end{array}$ & External stakeholder & $\begin{array}{l}\text { Specific stakeholders such as board of } \\
\text { directors, funders and patrons, government } \\
\text { agencies, decision makers, oversight } \\
\text { agencies, institutional supporters, staff, } \\
\text { members, volunteers, clients, } \\
\text { Wider public }\end{array}$ & $\begin{array}{l}\text { Multiple approach to satisfy different expectations of } \\
\text { stakeholders } \\
\text { Public as legitimating reference body balances all } \\
\text { stakeholders' relations as important }\end{array}$ \\
\hline $\begin{array}{l}\text { Rule-based } \\
\text { approach }\end{array}$ & Legality & Specific set of stakeholders & $\begin{array}{l}\text { Objective standards of assessment } \\
\text { Predictable and legal stream of information }\end{array}$ \\
\hline $\begin{array}{l}\text { Strategic } \\
\text { approach }\end{array}$ & Strategy & $\begin{array}{l}\text { Funders and other stakeholders } \\
\text { Nonprofit for securing resources such as } \\
\text { support from volunteers or money from } \\
\text { funders }\end{array}$ & $\begin{array}{l}\text { Tools to provide arguments to support the organization's } \\
\text { mission } \\
\text { Information on outcomes achieved Calculate expectations } \\
\text { nonprofit fulfills with its services }\end{array}$ \\
\hline $\begin{array}{l}\text { Learning } \\
\text { approach }\end{array}$ & $\begin{array}{l}\text { Organizational } \\
\text { learning }\end{array}$ & $\begin{array}{l}\text { Nonprofit for improvement } \\
\text { effectiveness }\end{array}$ & $\begin{array}{l}\text { Learning how to improve activities in order to achieve local } \\
\text { government mission } \\
\text { Creating a culture of accountability that is built on mission and } \\
\text { purpose }\end{array}$ \\
\hline
\end{tabular}

Source: Jäger (2014: 612)

The first four approaches, normative, relational, stakeholders and rule-based, strongly imply the influence of the environment over the organization. This is a huge argument for justifying the institutionalization of some practices, forms, structures and understandings within these organizations (Hanlon, 2004). Accounting, as a social practice (Potter, 2005), is profoundly shaped by the local and time-specific factors that characterize organizational context. Thus, researchers who follow an institutional approach advocate that accounting tools, like other organisational forms and practices, are institutionalized "when they are adopted because actors take them for granted, rather than because a rational choice process found them to be the most appropriate for the technical requirements of the task" (Järvinen, 2016: 862). However, according Thornton and Ocasio (2008: p. 101), "the approach to institutional logics integrates the structural, normative, and symbolic as three necessary and complementary dimensions of institutions, rather than separable structural (coercive), normative, and symbolic (cognitive) carriers", as suggested in our framework. Management control systems play a key role in the competitiveness of organizations (Voyant et al., 2017). Several theories attempt to explain managers' motivations for adopting certain models of accounting and management control (Ax \& Greve, 2017). One of the most striking aspects of accounting research in the last two decades has been the recognition that accounting practice is closely related to the organizational and institutional environment in which it is situated, 
i.e. accounting is seen as part of a larger context in which it acquires a specific meaning (Messner, 2016). In this sense, the New Institutional Sociology (NSI) interprets the behaviour of organizations, integrating them in the context in which they operate, thus recognizing the influence of the environment and explaining the process of adopting practices, rules and management routines as a mechanism of adaptation to the environment and the search for legitimacy. The institutional approach has had a special relevance in the analysis of organizational behaviour and organizational dynamics, making it possible to understand why organizations are as heterogeneous as, on the other hand, are so similar. However, studies that explicitly discuss the contexts of a particular industry are exceptions rather than the rule (Messner, 2016). Perhaps due to the complexity of the challenges it faces (Badillo et al., 2017), the automotive industry has been the cradle of applying management philosophies. Many of these practices are now a reference in several sectors of activity (Mesquita et al., 2013). In the more distant past, researchers in management accounting were essentially concerned with improving "practice" by developing normative templates to be applied by practitioners. However, evidence that the transfer of this knowledge to the world of practice did not occur alerted researchers to the possibility of not understanding the complexity of accounting practice in an imperfect world (Bromwich \& Scapens, 2016). Thus, in the 80 's, research begins to emerge guided by theoretical Behaviourist references (Hopper \& Bui, 2016). Several field surveys emerged that pointed to the gap between theory and practice (Bromwich \& Scapens, 2016). At this stage, the interest in studying the different practices in the respective context is revived, and the researchers take a subjective view of the phenomena, trying to understand the existing interactions. The emergence of these new theoretical and methodological alternatives elicited vigorous debates in the circles of researchers (Hopper \& Bui, 2016). The new theoretical approaches follow an interpretive paradigm and seek to explain the interaction between social structures and the meaning they acquire in the day to day of organizations. Within this perspective, accounting and its practices are interpreted as a socially constructed phenomenon (Busco \& Quattrone, 2018). The theorists of this line of thought begin to give more importance to the social, cultural and environmental aspects in which the organizations are inserted (Gomes et al., 2014), recognizing that decision-making not only deals with rationally treated neutral information, On the contrary, the decision-making process in organizations involves several factors, such as emotions, politics, culture, epistemological limitations or prejudices (Quattrone, 2016; Saukkonen et al., 2017). Consequently, there are proposals of theoretical frameworks that highlight and highlight the role of external pressures and institutions in the change in management accounting (ter Bogt \& Scapens, 2018). The organization is not limited to the sum of the elements that compose it, and in this sense, institutional theory seeks to explain organizational behaviour as a whole, relating it to the surrounding environment, which is a determining factor of organizational actions and decisions (Martins et al., 2014).

\section{Methodology}

\subsection{Portuguese social economy}

As noted above, social economy is not the only term used to mean that group of organizations "in which individuals, volunteer associations or other organized entities conduct business in the public interest and reinvest profit to achieve social goals" (Luyben, 2012). Indeed, from ancient times, "there are countless examples of social entrepreneurs that can be cited from around the world" (Schillaci et. al, 2017: 124), making it difficult to find a static and unique concept. Nevertheless, to actively promote the changes that our planet and its people need, first we ought to understand national dynamics. Evers and Laville (2004) pointed out the main differences between 'European' and 'American' definition of third sector, as it is shown in table 2:

\section{Table 2}

The organizations involved in third sector: 'European' versus 'American” definition

\begin{tabular}{ll}
\hline 'European' definition of third sector & 'American' definition of third sector \\
\hline $\begin{array}{l}\text { Emphasis on an analytical approach developing association typologies and } \\
\text { changes as well as the development of the economic dimension of all 'not- } \\
\text { for-profit' social economy organizations. }\end{array}$ & $\begin{array}{l}\text { Emphasis on a classificatory approach centred on a statistical interpretation } \\
\text { of the importance of a sector comprising all non-profit organizations }\end{array}$ \\
$\begin{array}{l}\text { Criterion of limits on private acquisition of profits: inclusion of cooperatives } \\
\text { and mutual aid societies }\end{array}$ & $\begin{array}{l}\text { Non-distribution constraint central, exclusion of cooperatives and mutual aid } \\
\text { societies }\end{array}$ \\
\hline
\end{tabular}

Source: Evers and Laville (2004: 13)

In a large collaborative research project on solidarity practices in Europe, conducted over 3 years and spanning 12 countries, Eschweiler et al (2019) found important evidences that, in spite of the diversity of country settings, namely in terms of politicoadministrative traditions, types of welfare capitalism, forms of the European Social Model, there are structural similarities across Europe. As it is expected, Portugal follows the 'European' definition. So, like many other European welfare states, Portugal has had a long tradition of partnership between state and third sector organizations. Since the beginnings of Portuguese nationhood in the 12th Century, several non-profit organizations have been connected to the Church. This close connection between the Church and the State has been critical in shaping the evolution of the Portuguese third sector all over the centuries. Franco et al. (2005: p. 2) argue that the current features of the Portuguese third sector reflected the country's long history of civil society development which "has been influenced by four major impulses: first, the country's Roman Catholic heritage; second, its long tradition of mutuality and self-help; third, its equally long history of authoritarian political control; and fourth, its recent democratic transition, which has led to a growing reliance of state agencies on private non-profit groups". Currently, in Portugal, the main criterion to be consider as a social and solidarity organization is (i) being a non-profit organization, (ii) have a social purpose at the top and (iii) result of private initiative. The condition of having social purpose at the top is in line 
with the concept of "building the human economy together" defined by Hart, Laville and Cattani (2010). Nevertheless, at the same time, these organizations are facing growing pressure to changing to a new management paradigm which is more closed to business. To deal with such a conflicting setting, these organizations tend to develop a kind of bipolar identity, they must be both, self-interested and mutual, to be economic as well as social, and like Hart et al (2010: p. 2) argue, "it is hard to be both". The representation of the relationship between the 'social' and the 'economic' as dual motivation (Hodgson, 2017) is likely to have influence on the accounting system.

\subsection{Data collection}

The survey was conducted in the second half of 2014 and the first half of 2015. Our sample included all types of organizations such as Foundations, Cooperative Associations or Private Institutions of Social Solidarity. The questionnaire was based on the seminal works of Abrahamson (1991) and Malmi (1999). Since it is an exploration study about which perspective(s) drive the adoption and diffusion of management accounting innovations, we did not intend to test hypotheses derived from these perspectives, rather we aimed to investigate the applicability of Abrahamson's framework to describe and establish propositions about the dynamic of the adoption and diffusion of one management accounting tool in Third Sector Organizations. The questionnaires contained sixteen close-ended questions. The questions were divided in two sections: 1. Demographic data obtained using nominal and interval scales; 2 . Data related to the proposed research questions and hypotheses. Questions number 15 and number 6 were adapted from Malmi (1999). Open-ended questions were designed to provide deeper insights about the accounting and management practices, as well as financial and no-financial report practices. The sample of our study is described in tables 3 to 9 . Table 3 characterizes the organizations in terms of their legal personality, including cooperatives, charities, foundations, associations with different motivations, private institutions of social solidarity and others. Of the total sample of 117 organizations, the majority ( $\mathrm{N}=75$ ) represented "Private Institutions of Social Solidarity" connected to cultural, recreational, sports and local development. Of the total sample of 117 organizations, thirty-nine were younger than 25 years old; forty-six were between 25 and 50 years old and twenty-five were above 50 years old.

Table 3

Sample - Legal form

\begin{tabular}{|c|c|c|c|c|c|c|c|c|}
\hline \multirow[t]{2}{*}{ Legal form } & \multirow[t]{2}{*}{ Total } & \multicolumn{2}{|c|}{$\begin{array}{l}\text { Younger organizations } \\
\text { (up to } 25 \text { years) }\end{array}$} & \multicolumn{2}{|c|}{$\begin{array}{l}\text { Middle-aged } \\
\text { organizations (between } \\
25 \text { and } 50 \text { years) }\end{array}$} & \multicolumn{2}{|c|}{$\begin{array}{l}\text { Oldest organizations } \\
\text { (above } 50 \text { years) }\end{array}$} & \multirow[t]{2}{*}{ No answer } \\
\hline & & $\mathrm{N}$ & $\% \mathrm{~N}$ & $\mathrm{~N}$ & $\% \mathrm{~N}$ & $\mathrm{~N}$ & $\% \mathrm{~N}$ & \\
\hline Cooperative & 6 & 0 & $0.0 \%$ & 3 & $2.6 \%$ & 3 & $2.6 \%$ & \\
\hline Charities (Misericórdias) & 11 & 2 & $1.7 \%$ & 1 & $0.9 \%$ & 8 & $6.8 \%$ & \\
\hline Foundation & 11 & 5 & $4.3 \%$ & 2 & $1.7 \%$ & 4 & $3.4 \%$ & \\
\hline $\begin{array}{l}\text { Associations (cultural, recreational, sports and } \\
\text { local development) }\end{array}$ & 6 & 1 & $0.9 \%$ & 2 & $1.7 \%$ & 3 & $2.6 \%$ & \\
\hline $\begin{array}{l}\text { Private Institution of Social Solidarity not } \\
\text { included in above categories }\end{array}$ & 75 & 30 & $25.6 \%$ & 38 & $32.5 \%$ & 7 & $6.0 \%$ & \\
\hline Other entities with legal personality & 1 & 1 & $0.9 \%$ & 0 & $0.0 \%$ & 0 & $0.0 \%$ & \\
\hline No answer & 7 & & & & & & & \\
\hline Total & 117 & 39 & $33.3 \%$ & 46 & $39.3 \%$ & 25 & $21.4 \%$ & 7 \\
\hline
\end{tabular}

Source: Own Elaboration

As shown in table 4, the majority of participants assumed the "support to youth and children" or "protection of senior and/or invalid citizens" as its main mission. However, "family support" and "support for social and community integration" are also representative categories.

Table 4

Sample - Organization mission

\begin{tabular}{|c|c|c|}
\hline Areas of Action/Influence of the Institution & $\mathbf{N}$ & $\% \mathbf{N}$ \\
\hline Support to youth and children & 77 & $65.8 \%$ \\
\hline Protection of senior and/or invalid citizens & 73 & $62.4 \%$ \\
\hline Family support & 54 & $46.2 \%$ \\
\hline Support for social and community integration & 39 & $33.3 \%$ \\
\hline Health promotion and protection & 24 & $20.5 \%$ \\
\hline Education and professional training & 23 & $19.7 \%$ \\
\hline Population house problem solving & 9 & $7.7 \%$ \\
\hline Other & 16 & $13.7 \%$ \\
\hline
\end{tabular}

Source: Own Elaboration

The sample is further characterized in Tables 5 to 7, namely in terms of number of workers (Table 5), number of volunteer workers (Table 6), revenue and maturity (Table 7). As we can see, $46.2 \%$ of the sample included organizations with 11 to 50 workers. Table 6 shows that $23.1 \%$ of the sample had no volunteer workers, while almost $37 \%$ have up to nine volunteer workers and only a small percentage $(4.3 \%)$ reported the collaboration above 29 volunteers. 
Table 5

Sample - Number of Workers

\begin{tabular}{lcc}
\hline Number of workers & $\mathbf{N}$ & $\mathbf{~}$ \\
\hline Up to 10 workers $] 0 ; 10]$ & 17 & \\
Between 10 and 50 workers ]10;50] & 54 & $4.5 \%$ \\
Above 50 workers $>50$ & $46.2 \%$ & 44 \\
No answer & $2 \%$ & $2 \%$ \\
\hline
\end{tabular}

Source: Own Elaboration

\section{Table 6}

Sample - Number of Volunteer

\begin{tabular}{lcc}
\hline & $\mathbf{N}$ & $\mathbf{~}$ \\
\hline No Volunteer Workers & 27 & \\
Volunteer Workers [1 to 9] & $23.1 \%$ & 43 \\
Volunteer Workers [10 to 29] & $36.8 \%$ & 23 \\
Volunteer Workers [30 to98] & 5 & $19.7 \%$ \\
No answer & $4.3 \%$ & 19 \\
\hline
\end{tabular}

Source: Own Elaboration

Table 7 shows the amount of revenue of participants. It is important to note that $37.6 \%$ of the sample had an amount of revenues above 500,000€.

Table 7

\begin{tabular}{|c|c|c|}
\hline (euros) & $\mathbf{N}$ & $\%$ \\
\hline Less than 100,000 & 10 & $8.5 \%$ \\
\hline Between $[100,000-249,000]$ & 13 & $11.1 \%$ \\
\hline Between [249,000-499,999] & 21 & $17.9 \%$ \\
\hline Above 500.000 & 44 & $37.6 \%$ \\
\hline No answer & 29 & 24.8 \\
\hline Total & 117 & $100 \%$ \\
\hline
\end{tabular}

Source: Own Elaboration

In terms of maturity, the sample included 40 organizations (34.2\%) that were less than 25 years old, 46 organizations (39.3\%) aged between 25 and 50 years, and 25 organizations (21.4\%) older than 50 years (Table 8 ).

\section{Table 8}

Sample - Maturity

\begin{tabular}{|c|c|c|}
\hline & $\mathbf{N}$ & $\% \mathbf{N}$ \\
\hline$=<25$ years old & 40 & $34.2 \%$ \\
\hline$>25$ and $=<50$ years old & 46 & $39.3 \%$ \\
\hline$>50$ years old & 25 & $21.4 \%$ \\
\hline No answer & 6 & $5.1 \%$ \\
\hline
\end{tabular}

Source: Own Elaboration

Related to the source of income of these organizations, Table 9 presents the results for three consecutive years. The respondents distributed 100 points from the following sources of funding: Social Security; European Social Fund; services rendered to members or equivalent; services rendered to third parties; property incomes and other relevant source of income. The average of the responses, for the three years, shows stability in the source of income. The source of income most important is the Social Security (with more than average with 40 points) and the less is property incomes, which received only an average of 2 points.

\section{Table 9}

Sample - Source of income

\begin{tabular}{|c|c|c|c|}
\hline & $\begin{array}{l}\text { Average three years-previous } \\
\text { (Standard deviation) }\end{array}$ & $\begin{array}{l}\text { Average Two Years-previous } \\
\text { (Standard deviation) }\end{array}$ & $\begin{array}{c}\text { Average Last Year (Standard } \\
\text { deviation) }\end{array}$ \\
\hline Social Security & $42(28)$ & $41(27)$ & $42(28)$ \\
\hline European Social Fund & $3(12)$ & $4(12)$ & $3(11)$ \\
\hline Donations and similar & $8(16)$ & $8(16)$ & $8(16)$ \\
\hline Services rendered to members or equivalent & $10(20)$ & $10(20)$ & $10(20)$ \\
\hline Services rendered to third parties & $23(27)$ & $24(28)$ & $24(28)$ \\
\hline Property incomes & $2(6)$ & $2(7)$ & $2(6)$ \\
\hline Other relevant source of income & $9(17)$ & $9(17)$ & $9(18)$ \\
\hline
\end{tabular}
Source: Own Elaboration

\section{Results and Discussion}

Since there has been little investigation about accounting practices in Portuguese third sector organizations, the first question was "what are the accounting tools presently used by third sector organizations?" The answer could not be obtained directly 
from any database or elsewhere. So, data were collected through the questionnaire. The results, presented in Table 10, have some surprises.

Table 10

What are the accounting tools most used in the third sector?

\begin{tabular}{|c|c|c|}
\hline Tools & $\mathbf{n}$ & $\% \mathrm{n}$ \\
\hline Budget & 93 & $79.5 \%$ \\
\hline Financial Accounting & 87 & $74.4 \%$ \\
\hline Management Accounting (traditional methods) & 74 & $63.2 \%$ \\
\hline Human Resources Statement ("Balanço Social") & 49 & $41.9 \%$ \\
\hline Sustainability Report & 17 & $14.5 \%$ \\
\hline Balanced Scorecard & 7 & $6.0 \%$ \\
\hline Benchmarking & 5 & $4.3 \%$ \\
\hline Activity Based Costing (ABC) & 4 & $3.4 \%$ \\
\hline Total Quality Management & 4 & $3.4 \%$ \\
\hline Any accounting tool is used & 4 & $3.4 \%$ \\
\hline
\end{tabular}

Table 10 presents the type of tools used by the organizations included in the sample. With regard to implementation, the budget is the instrument with the highest index of implementation with $79.5 \%$ of total sample, followed by the financial accounting with $74.4 \%$. The traditional methods of management accounting were adopted by $63.2 \%$. However, Activity Based Costing, Balanced Scorecard, Benchmarking and TQM have a very tiny diffusion within the sample group. The Human Resources Statement obtaining $41.9 \%$. This is surprising, since in Portugal it is compulsory only for organizations with more than 100 workers. To answer the second question (“Why these accounting tools were adopted?") participants were asked to indicate, on a 7-point scale ( 1 = Not important; 7 = Very important), how much each of the items (see Table 11) led to the adoption of each of the accounting tools currently used. Table 11 shows the possible reasons grouped in four categories: "Efficient-choice (1RC)", "Forced selection (2CI)", "Fad (3MI)" and "Fashion (4NI)". First, it is imperative to explain that the "R>=4" in figure 12 means the number of participants who rated the item equal or higher than four on the 7-point scale $(1=$ Not important; $7=$ Very important). Also, it is quite relevant that the most participants marked only one or two reasons for the decision about the adoption of each accounting tool. We interpret that as demonstration of clarity about the motivations. Table 11 shows that the "legal imposition" is the item most identified, with " $\mathrm{R}>=4$ " for traditional accounting tools like Budget; Financial Accounting; Management Accounting. As mentioned before, the major client of the Portuguese third sector is the State. Indeed, the majority of non-profit organizations are financed by public organizations, both directly through operating subsidies or based in outsourcing relationships. This results in a submission relationship, as described by (DiMaggio and Powell 1983). It means that the more powerful actors (state and funding bodies) may impose certain procedures and practices, such as legal frameworks or budget schedules, to induce the less powerful actors to interact with them. This can be interpreted as "resource-based accountability", i.e., decisions of third sector organizations about their accounting models are driven by expectations of the resource owners (Hug \& Jäger, 2014: p. 772).

The legal imposition of Financial Accounting derives from the legal frame of the organization. Indeed, Financial Accounting is mandatory for every organization with legal and financial autonomy. However, the imposition of a Budget or Management Accounting only happens when third sector organizations have a contractual relationship or a government-non-profit partnership. This is understandable since, as pointed out by Bhimani et al. (2016: 296), "performance assessment and measurement costs thus permeate most aspects of outsourcing controls". This control rule of accounting is not surprising, since the Portuguese public sector has been focused on financial performance aspects.

This tendency can, at least partially, explain why "Social Security", identified in Table 9 as the main funding body of participants, imposes a budget control and an internal cost accounting system on those organizations they support. Indeed, "several studies informed by institutional theory show that the financial controls [were] devised to discipline resource use in public-sector organizations" (Brignall and Modell, 2000:283). These coercive pressures from funding bodies for improving financial performance occurred simultaneously with other forces of a less coercive nature, namely, the advice of the accountant ("we were advised by our accountant") or the perception that "management processes required new management tools". While the former is in line with a typical example of normative isomorphism, the second is informed by rational choice theory. This apparent contradiction is in line with the argument of Brignall and Modell (2000: 300) that institutional theorists over-emphasize the adaptive nature of organizational behaviour, and that it is important "to complement this with a view of management as an intentional and pro-active agent". If we look at the data at a more general level, the results still show that the dominant forces that led to the implementation of the accounting tools used in Portuguese third sector are coercive in nature. Figure 2 summarizes the reasons behind the adoption of each accounting tool. 


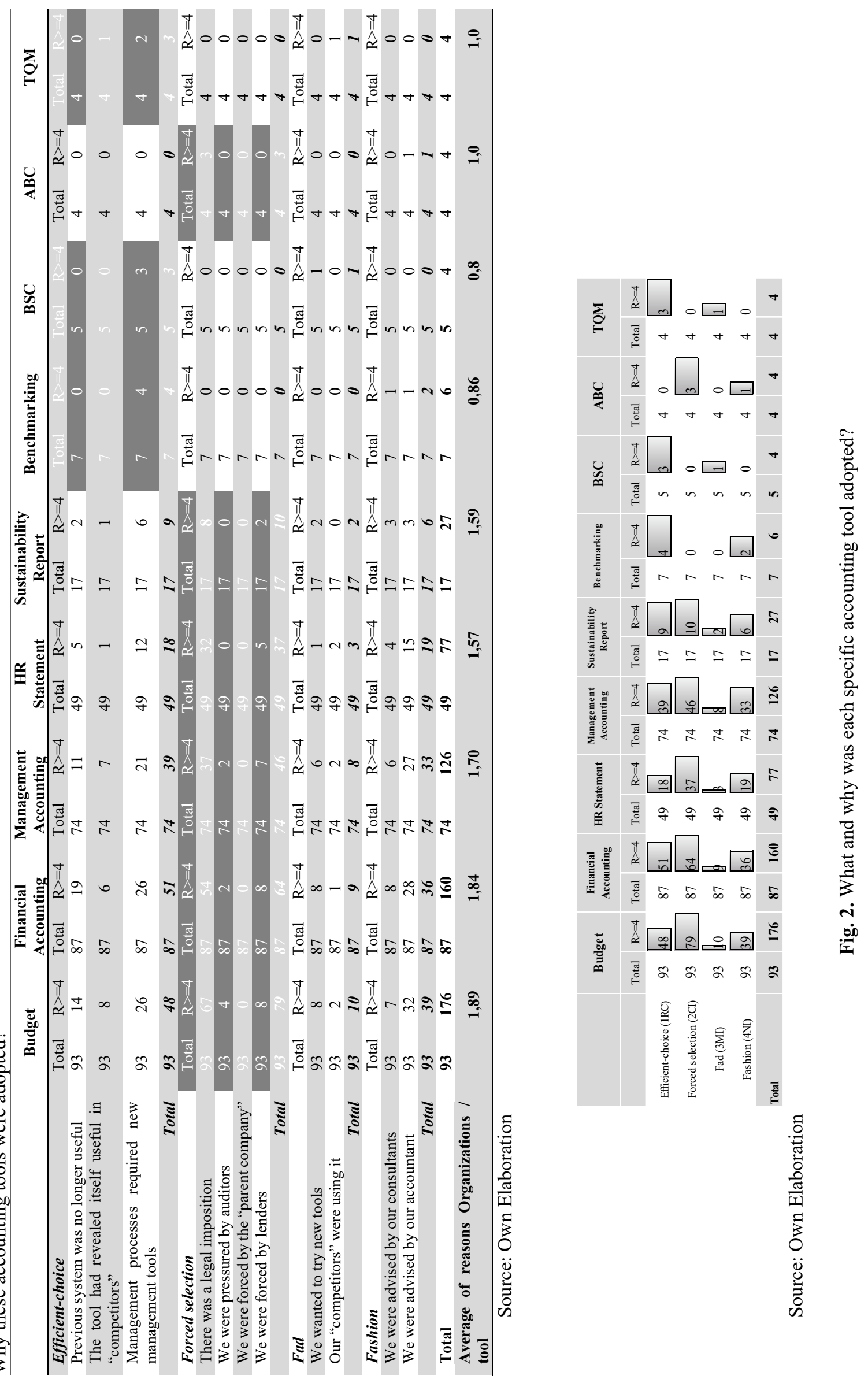


Fig. 2 reinforces the evidence that the decisions about the adoption of accounting tools were driven simultaneously by "coercive isomorphic practices" and "rational choice". Thus, this paper proposes that these two general models (over-rational vs. oversocialised) should not be seen as two opposing views, but rather as two complementary dimensions of decision-making processes and behaviours. Indeed, decision-making deal with a mix of rational and sociological factors, as argued by Quattrone (2016) and Saukkonen et al. (2017).

\section{Conclusion}

According to DiMaggio (2003), a huge number of the studies about non-profit organizations have been seduced by the "fallacy of essentialism" which means that they assume that these organizations are immutable. However, the relationship between the state and the third sector organizations, the way they interact, and the role of the third sector in providing public services are controversial issues (Brown and Troutt, 2007) and change over the time. Thus, we assume that "non-profitness has no single transhistorical or transnational meaning; non-profit-sector functions, origins, and behaviour reflect specific legal definitions, cultural inheritances, and state policies in different national societies" (DiMaggio \& Anheier, 1990: p. 137) and starting from the place that management accounting systems and practices constitute organizational rules and routines (Burns and Scapens, 2000), this paper describes the reasons behind the adoption of accounting tools used by third Portuguese sector organizations. The theoretical ideas of the new institutional theory were compared with rational choice theory assumptions. The research design was based on earlier work of Abrahamson (1991) and Malmi (1999). The results support the theoretical perspective of institutionalism. Indeed, third sector organizations operating in Portugal use essentially traditional accounting tools like financial accounting statements, cost accounting and budgeting, and there are clear evidences of coercive isomorphic behaviours. Since there has been little investigation about accounting practices in Portuguese third sector organizations, our results cannot be compared with past results. It is not an easy task to show the utility of academic work outside of academic circles (Chapman, 2015). Even so, this paper contributes to the current debate relating to what, how and why third sector organizations adopt certain accounting tools and in what kind of decisions they are used. On the practical side, the study provides politicians and government officials with relevant information to better define the way public policies should support for third sector organizations' activities and management. Despite its contribution, authors recognize some research limitations. The main limitations of the research stem from the questionnaire. Indeed, although questionnaire was design based on earlier literature, construct validity was not assured. Moreover, there is a sample bias because of data collection procedures. To deeply understand the reasons behind the adoption of accounting information tools in Portuguese third sector organizations, there is a need for longitudinal case study which allow the authors to understand how and why the accounting systems are designed and used in real context. This future research should follow a more comprehensive framework as that proposed in ter Bogt and Scapens (2018). Moreover, for future research, we suggest a qualitative approach in order to identify the hybrid nature of third sector organizations, where plural institutional logics interact (Skelcher \& Smith, 2015).

\section{References}

Abrahamson, E. (1991). Managerial fads and fashions: the diffusion and rejection of innovations. Academy of Management Review, 16(3), 586-612.

Anheier, H. K., \& Seibel, W. (2013). The third sector: Comparative studies of non-profit organizations (Vol. 21). Walter de Gruyter.

Bach-Mortensen, A. M., Lange, B. C., \& Montgomery, P. (2018). Barriers and facilitators to implementing evidence-based interventions among third sector organisations: a systematic review. Implementation Science, 13 (1), 103.

Bhimani, A., Lopes, A., \& De Aquino, A. C. B. (2016). Measurement costs and control in outsourcing relationships. International Journal of Managerial and Financial Accounting, 8(3/4), 296-318.

Bisman, J. (2010). Postpositivism and Accounting Research: A (Personal) Primer on Critical Realism, Australasian Accounting, Business and Finance Journal, 4(4), 3-25.

Brierley, J. A. (2013). The uses of product costs in decision making in British manufacturing industry. International Journal of Managerial and Financial Accounting, 5(3), 294-309.

Brignall, S., \& Modell, S. (2000). An institutional perspective on performance measurement and management in the 'new public sector'. Management Accounting Research, 11(3), 281-306.

Bromwich, M., \& Scapens, R. W. (2016). Management accounting research: 25 years on. Management Accounting Research, 31, 1-9.

Brown, L., \& Troutt, E. (2007). Reporting does not equal accountability! The importance of funding characteristics and Process on Accountability. International Journal of Public Administration, 30(2), 209-225.

Bryman, A., \& Bell, E. (2015). Business research methods. Oxford University Press, USA.

Burns, J., \& Scapens, R. W. (2000). Conceptualizing management accounting change: an institutional framework. Management Accounting Research, 11(1), 3-25. 
Chapman, C. S. (2015). Researching accounting in health care: considering the nature of academic contribution. Accounting \& Finance, 55(2), 397-413.

Coluccia, D., Fontana, S., \& Solimene, S. (2017). The influence of voluntary disclosure on the volatility of firms from a multistakeholder perspective. International Journal of Managerial and Financial Accounting, 9(1), 44-67.

Corry, O. (2010). Defining and theorizing the third sector. In Third sector research (pp. 11-20). Springer, New York, NY.

DiMaggio, P. (1988). Interest and agency in institutional theory. In Lynne G. Zucker (ed.), Institutional Patterns and Organizations: Culture and Environment. Cambridge, MA: Ballinger, 3-22.

DiMaggio, P. (2003). An Ecological Perspective on Non-profit Research. In H. K. Anheier \& A. Ben-Ner (Eds.), The Study of the Non-profit Enterprise: Theories and Approaches (pp. 311-320). Boston, MA: Springer US.

DiMaggio, P. J., \& Anheier, H. K. (1990). The sociology of non-profit organizations and sectors. Annual Review of Sociology, 16(1), 137-159.

Dimaggio, P., \& Powell, W. (1983). The iron cage revisited: Institutional isomorphism and collective rationality in organizational fields. American Sociological Review, 48(2), 147-160.

Eschweiler, J., Svensson, S., Mocca, E., Cartwright, A., \& Nielsen, L. V. (2019). The Reciprocity Dimension of Solidarity: Insights from Three European Countries. VOLUNTAS: International Journal of Voluntary and Non-profit Organizations, $1-13$.

Evers, A., \& Laville, J. L. (2004). The third sector in Europe. Cheltenham: Edward Elgar. USA.

Franco, R. C., Sokolowski, S. W., Hairel, E. M., \& Salamon, L. M. (2005). The Portuguese non-profit sector in comparative perspective. Universidade Católica Portuguesa and Johns Hopkins University.

Gazley, B., \& Brudney, J. L. (2007). The purpose (and perils) of government-non-profit partnership. Non-profit and Voluntary Sector Quarterly, 36(3), 389-415.

Gomes, D. (2007). Accounting change in central government: the institutionalization of double entry bookkeeping at the Portuguese Royal Treasury (1761-1777). Tese de Doutoramento, Universidade do Minho, Braga.

Hanlon, G. (2004). Institutional forms and organizational structures: homology, trust and reputational capital in professional service firms. Organization, 11(2), 186-210.

Hart, K., Laville, J. L., \& Cattani, A. (2010). Building the human economy together. The Human Economy: a citizen's guide. Cambridge: Polity.

Henriksen, L.S, Smith, S.R., \& Zimmer, A. (2012). At the eve of convergence? Transformations of social service provision in Denmark, Germany, and the United States. Voluntas: International Journal of Voluntary and Non-profit Organizations, 23(2), 458-501.

Hopper, T., \& Bui, B. (2016). Has management accounting research been critical? Management Accounting Research, 31, 1030.

Hopper, T., \& Major, M. (2007). Extending institutional analysis through theoretical triangulation: regulation and activity-based costing in Portuguese telecommunications. European Accounting Review, 16(1), 59-97.

Hug, N., \& Jäger, U. P. (2014). Resource-based accountability: A case study on multiple accountability relations in an economic development non-profit. Voluntas: International Journal of Voluntary and Non-profit Organizations, $25(3), 772-796$.

ILO (2011). Social Business Plan Competition Handbook. ILO Cataloguing in Publication Data ISBN 978-92-2-124872-9 (print) 978-92-2-124873-6 (web pdf)

Jäger, U. (2014). Managing Social Businesses: Mission, Governance, Strategy and Accountability (2 ${ }^{\text {nd }}$ Edition). Basingstoke: Palgrave MacMillan.

Järvinen, J. T. (2016). Role of management accounting in applying new institutional logics. A comparative case study in the non-profit sector. Accounting, Auditing \& Accountability Journal, 29(5).

Lindsay, C., Osborne, S. P., \& Bond, S. U. E. (2014). The 'new public governance' and employability services in an era of crisis: Challenges for third sector organizations in Scotland. Public Administration, 92(1), 192-207.

Luyben, T. (2011). National concept for social economy. https://www.eurofound.europa.eu/publications/article/2011/nationalconcept-for-social-economy, accessed 21.02.2019

Major, M. J. (2017). O positivismo e a pesquisa 'alternativa' em Contabilidade. Revista Contabilidade \& Finanças, 28(74), 173-178.

Malmi, T. (1999). Activity-based costing diffusion across organizations: an exploratory empirical analysis of Finnish firms. Accounting, Organizations and Society, 24(8), 649-672.

Meyer, J. W., \& Rowan, B. (1977). Institutionalized organizations: Formal structure as myth and ceremony. American Journal of Sociology, 83, 340-363.

Meyer, J.W., \& Scott, W.R. (1983). Centralization and the legitimacy problems of local government. In J. W. Meyer \& W. R. Scott (Eds), Organizational environments: Ritual and rationality (pp. 199-215). Beverly Hills. Sage

Moll, J., Burns, J., \& Major, M. (2006). Institutional theory. In Hoque (Ed.). Methodological Issues in Accounting Research: Theories, Methods and Issues (pp. 183-205). Spiramus Press, London.

Oyadomari, J. C., Cardoso, R. L., Mendonça Neto, O. R., \& Lima, M. P. (2008). Fatores que influenciam a adoção de artefatos de controle gerencial nas empresas brasileiras. Um estudo exploratório sob a ótica da teoria institucional. Revista de Contabilidade e Organizações, 2(2), 55-70. 
Parker, L. D. (2012). Qualitative management accounting research: Assessing deliverables and relevance. Critical Perspectives on Accounting, 23(1), 54-70.

Potter, B. N. (2005). Accounting as a social and institutional practice: Perspectives to enrich our understanding of accounting change. Abacus, 41(3), 265-289.

Potts, J., \& Hartley, J. (2015). How the social economy produces innovation. Review of Social Economy, 73(3), $263-282$.

Rossetto, C. R., \& Rossetto, A. M. (2005). Teoria institucional e dependência de recursos na adaptação organizacional: uma visão complementar. RAE-eletrônica, 4(1), 1-22.

Salamon, L. M., \& Sokolowski, W. (2016). Beyond non-profits: Re conceptualizing the third sector. Voluntas: International Journal of Voluntary and Non-profit Organizations, 27(4), 1546-1561.

Schillaci, C. E., Romano, M., Nicotra, M., \& Ottavia, T. (2017). Social entrepreneurs as change catalysts: evidences from case studies. International Journal of Managerial and Financial Accounting, 9(2), 124-139.

Skelcher, C., \& Smith, S. R. (2015). Theorizing hybridity: Institutional logics, complex organizations, and actor identities: The case of non-profits. Public administration, 93(2), 433-448.

Suh, T., \& Amine, L. S. (2007). Defining and managing reputational capital in global markets. Journal of Marketing Theory and Practice, 15(3), 205-217.

Swanson, R. A. (2005). The process of framing research in organizations. Research in organizations: Foundations and methods of inquiry, 11-26.

Taylor, M., \& Warburton, D. (2003). Legitimacy and the Role of UK Third Sector Organizations in the Policy Process. Voluntas: International Journal of Voluntary and Non-profit Organizations, 14(3), 321-338.

ter Bogt, H. J., \& Scapens, R. W. (2018). Institutions, Situated Rationality and Agency in Management Accounting: Extending the Burns and Scapens Framework.

Thornton, P. H., \& Ocasio, W. (2008). Institutional logics. The Sage handbook of organizational institutionalism, 840, 99-128.

Vaivio, J. (2008). Qualitative management accounting research: rationale, pitfalls and potential. Qualitative Research in Accounting \& Management, 5(1), 64-86.

Walker, S. P. (2016). Revisiting the roles of accounting in society. Accounting, Organizations and Society, 49, 41-50.

Westlund, H. (2003). Social economy and employment-the case of Sweden. Review of Social Economy, 61(2), $163-182$.

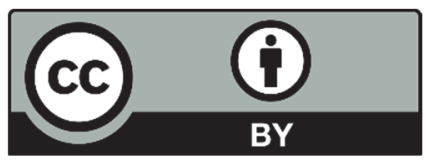

(C) 2020 by the authors; licensee Growing Science, Canada. This is an open access article distributed under the terms and conditions of the Creative Commons Attribution (CC-BY) license (http://creativecommons.org/licenses/by/4.0/). 